\title{
STATUS GIZI ANAK REMAJA AWAL DIWILAYAH PESISIR DAN PEGUNUNGAN KABUPATEN BULUKUMBA
}

\author{
${ }^{1}$ Nur Rahman \\ ${ }^{2}$ Fitriani \\ ${ }^{3}$ Asnidar
}

\begin{abstract}
${ }^{1}$ Mahasiswa Keperawatan, Stikes Panrita Husada Bulukumba, Indonesia
${ }^{2}$ Departemen Keperawatan Anak dan Maternitas, Stikes Panrita Husada Bulukumba, Indonesia

${ }^{3}$ Departemen Keperawatan Anak dan Maternitas, Stikes Panrita Husada Bulukumba, Indonesia
\end{abstract}

\author{
Alamat Keresponden \\ Nur Rahman \\ Desa Bonto Mate'ne Kecamatan \\ Rilau Ale' Kab. Bulukumba \\ Hp. 085397500844 \\ Email: rahman_n10@yahoo.com
}




\begin{abstract}
ABSTRAK
Status gizi merupakan sumber energi, pertumbuhan dan pemeliharaan jaringan tubuh, serta pengatur proses tubuh, keadaan tubuh sebagai akibat komsumsi makanan dan pengunaan zat gizi. Tujuan penelitian ini adalaha untuk mengetahui gambaran staus gizi wilayah pesisir dan pegunungan di Kabupaten Bulukumba. Desain penelitian ini menggunakan desain deskriktif dengan pendekatan "study komporatif".jumlah populasi dan sampel pada penelitian ini yaitu 441 dengan menggunakan metode total sampling. Dari hasil yang di lakukan peneliti pada 441 responden, didapatkan status gizi sangat kurus 4 responden, kurus 25 responden, normal 341 responden, gemuk 44 responden, dan obesitas 27 responden Status gizi anak remaja awal di SMPN 14 dan 18 Bulukumba diwilayah pegunungan memiliki status gizi obesitas sedangkan status gizi anak remaja awal di SMPN 32 Bulukumba diwilayah pesisir memiliki status gizi gemuk. Agar penelitian ini dapat memberikan informasi mengenai Status Gizi anak remaja diwilayah Pegunungan dan Pesisir di Kabupaten Bulukumba, menjadi informasi yang berguna untuk semua pihak tertentu serta dapat menjadi bahan referensi untuk penelitian selanjutnya.
\end{abstract}

\title{
Keywords: Status Gizi, Remaja Awal
}

\begin{abstract}
ABSTRAK
Nutritional status is a source of energy, growth and maintenance of body tissues, as well as regulating body processes, body condition as a result of food consumption and nutrient use. The purpose of this study was to determine the picture of the nutritional status of coastal and mountainous regions in Bulukumba Regency. The design of this study used a descriptive design with a "comparative study" approach. The population and sample in this study were 441 using the total sampling method. From the results conducted by researchers on 441 respondents, obtained very thin nutritional status 4 respondents, 25 respondents thin, normal 341 respondents, 44 obese respondents, and 27 respondents obesity Nutritional status of early adolescents in SMPN 14 and 18 Bulukumba in mountainous regions have nutritional status obesity while the nutritional status of early adolescents at SMPN 32 Bulukumba in the coastal area has a fat nutritional status. So that this research can provide information about the Nutrition Status of adolescents in the Mountains and Coastal regions in Bulukumba Regency, it becomes useful information for all specific parties and can be a reference material for further research.
\end{abstract}

\section{Keywords: Nutritional Status, Early Adolescents}




\section{PENDAHULUAN}

Status gizi merupakan sumber energi, pertumbuhan dan pemeliharaan jaringan tubuh, serta pengatur proses tubuh, keadaan tubuh sebagai akibat konsumsi makanan dan penggunaan zat gizi, dimana zat gizi sangat dibutuhkan oleh tubuh. Akan tetapi mengomsumsi gizi lebih akan menyebabkan kegemukan atau obesitas. Kelebihan energi yang di komsumsi disimpang didalam jaringan dalam bentuk lemak. (Almaster, 2009 dan Auliyah \& Budiyono 2005).

Sataus gizi pada Daerah perbukitan dominan akan sayur-mayur, dan hasil perkebunan, sebagian besar adalah petani sawah atau ladang cenderung mengkonsumsi makanan sumber protein nabati yang menyebabkan perbedaan jenis dan jumlah pangan yang biasa dikomsumsi sehari-hari dan di masyarakat. di daerah pantai yang sebagian besar adalah nelayan cenderung mengkomsumsi makanan sumber protein hewani yang berasal dari laut, daerah pantai dominan akan produksi ikan dan hasil laut. Aulia \& Budiono, (2015).

Menurut WHO pada tahun 2015 terdapat 42 juta anak yang kelebihan berat badan, angka tersebut naik 31 juta dari tahun 2000, WHO Global Nurition Report 2016, Tren menunjukkan bahwa jumlah tersebut akan meningkat. Jumlah anak yang mengalami kelebihan berat badan akan meningkat menjadi 70 juta jiwa pada tahun 2025 jika kecenderungan terus berlanjut. Disisi lain negara Indonesia juga mengalami masalah kelebihan gizi, selain mengalami masalah kekurangan gizi. Angka obesitas pada anak di Indonesia sebanyak $11,5 \%$ dan berada pada urutan ke-21 di dunia. (Faridah \& Indriani, 2017).

Para ahli menyebutkan bahwa overweight dan obesitas pada anak, akan berpengaruh pada fisik dan psikososial. Diantaranya penyakit jantung koroner, diabetes melitusdan hipertensi serta akan berdampak terhadap tumbuh kembang anak. Dan dampak yang akan di timbulkan pada anak kuraan percaya diri, ganguan psikosossial dna problema tingkahlaku. Dan peingkatan resiko jenis kanker seperti kanker payudara, kolon endometrium, esofagus, ovaarium, serviks dan lainya. (Prasetioni \& Febrijanto, 2010; dannari, maluyu, \& Bala 2013).

Peneliti melakukan pengumpulan data awal dari wilayah Pegunungan dan Pesisir yang dilakukan peneliti pada bulan Maret 2018, disekolah SMPN 18 Bulukumba, SMPN 14 Bulukumba wilayah pegunungan ketinggian 100 s/d 500 meter dari permukaan air laut dan SMPN 32 Bulukumba dan di wilayah pesisir dengan ketinggian antara 0/25 meter di atas permukaan air laut. Di dapatkan informasi 
dari ke tiga sekolah tersebut bahwa siswa sedang melakukan kegiatan belajar. Terdapat tiga jumlah sekolah yang akan menjadi sampel SMPN 18 dan SMP 14 Bulukumba kelas VII 210 orang diwilayah pegunungan, dan SMPN 32 Bulukumba kelas VII 231 di wilayah pesisir. Dimana peneliti tertarik dari populasi yang ada untuk membandingkan kejadian obesitas di wilayah pegunungan dan pesisir dengan jumlah populasi pada anak usia sekolah sekitar 441 dari keseluruhan populasi yang ada di wilayah pegunungan dan pesisir.

Untuk mengetahui ada perbanbandingan Status Gizi pada anak remaja di wilayah pegunungan dan wilayah pesisir di Kabupaten Bulukumba.

\section{METODE}

Penelitian ini menggunakan penelitian deskriftif dengan pendekatan study komporatif karena penelitian ini variabel sebab atau resiko dan akibat atau kasus yang terjadi pada objek penelitian diukur dan dikumpulkan secara simultan atau dalam waktu yang bersamaan (Setiadi, 2013). Yang dinilai adalah perbandingan ststus gizi pada anak di wilayah pesisir dan pegunungan Kabupaten Bulukumba. Populasi adalah keseluruhan subjek penelitian yang akan diteliti (Setiadi, 2013). Maka populasi penelitian ini adalah seluruh anak SMPN 18, dan SMPN 14 Bulukumba kelas VII, wilayah pegunungan dan SMPN 32 dan SMPN di pesisir. Jumlah populasi dari pengunungan adalah 210 orang dan jumlah dari populasi dari pesisir 231 orang jadi, jumlah populasi pada anak usia sekolah sekitar 441 dari keseluruhan populasi yang ada di wilayah pegunungan dan pesisir.

Sampel penelitian adalah sebagaian dari keseluruhan obyek yang diteliti dan dianggap mewakili seluruh populasi (Setiadi, 2013). Teknik pengambilan sampel dengan cara total sampling adalah teknik pengambilan sampel dimana jumlah sampel sama dengan populasi. (Setiadi, 2013). Jumlah sampel dari penelittian ini adalahn 441 responden.

Penelitian ini menggunakan instrumen penelitian berupa observasi, timbangan injak dengan merek timbangan GEA dan microtise dengan merek GEA. Observasi adalah kegiatan pengumpulan data melalui pengamatan langsung terhadap aktivitas responden atau partisipan yang terencana, dilakukan secara aktif dan sistematis, Timbangan injak adalah alat ukur yang digunakan untuk menilai berat badan $(\mathrm{Kg})$., Microtoise adalah alat ukur yang digunakan untuk menilai tinggi badan $\left(\mathrm{m}^{2}\right)$.

Data dianalis berdasarkan skala ukur dan tujuan penelitian dengan menggunkan perangkat lunak komputerisasi data analisis secara univariat analisis univariat 
di sajikan untuk mendikskripsikan variabel-variaabbel penelitian dengan menggunakan tabel distribusi frekuensi dan presentasi menggunakan dengan bantuan computer.

\section{HASIL}

Berdasarkan Tabel 1 menunjukkan sebagian besar jenis kelamin perempuan $250(56,7 \%)$ dan sebagian besar umur responden berada pada kategori umur 13 tahun 263 responden $(59,6 \%)$. Berdasarkan tabel 2 menunjukkan status gizi anak remaja awal dengan nilai yaitu status gizi normal 341 responden $(77,3 \%)$ nilai status gizi terendah yaitu status gizi sangat kurus 4 responden $(0,9 \%)$. Berdasarkan tabel 3 hasil crostab menunjukkan bahwa status gizi anak remaja awal di wilayah pesisir berada pada umur 13 tahun dengan status gizi normal sebanyak 110 responden. Berdasarkan tabel 4 hasil crostab menunjikkan bahwa status gizi anak remaja awal di wilayah pegunungan berada pada umur 13 tahun dengan status gizi normal sebanyak 109 responden.

\section{PEMBAHASAN}

Status gizi di wilayah Pesisir hal ini menimbulkan gambaran gizi dipesisir di temukan sangat kurus 3 responden $(1,3 \%)$,kurus di wilayah Pesisir di temukan 18 responden $(7.8 \%)$, anak remaja yang berstatus gizi normal diwilayah Pesisir 177 (76,6\%) responden, anak yang berstatus gizi gemuk diwilayah Pesisir yaitu 23 $(10,0 \%)$, status gizi obesitas ditemukan anak ramaja awal obesitas 10 responden $(4,3 \%)$. Ini menunjukkan status gizi anak remaja awal di antara wilayah Pesisir dengan sumber pendapatan pangan dengan letak wilayah masing-masing di mana pada wilayah Pesisir dengan pendapatan sumber makanan dari laut yang lebih dominan dengan hewani seperti ikan segar.

Hal ini sesuai dengan teori bahwa Gizi lebih menyebabkan kegemukan atau obesitas. Kelebihan energi yang di komsumsi di simpang didalam jaringan dalam bentuk lemak. Kegemukan merupakan salah satu faktor resiko dalam terjadinya berbagai penyakit seperti hipertensi, diabetes, jantung koroner, hati, dan kantung empeduh (Almaster, 2009).

Penelitian ini tidak sejalan dengan penelitian yang di kemukakan Yulni dengan judul Hubungan Asupan Zat Gizi Makro Dengan Status Gizi Pada Anak Sekolah Dasar Di Wilayah Pesisir Kota Makassar, bahwa Wilayah pesisir merupakan lingkungan permukiman nelayan pada umumnya merupakan kawasan kumuh mempunyai karakteristik dan problem yang unik dan Kompleks, lingkungan yang sangat terbatas dengan tingkat pelayanan pemenuhan kesehatan yang terbatas. Dari Jumlah responden 150 sangat kurus $5(3,3 \%)$ Kurus 25 responden 
(16,7\%) Normal 116 responden $(77, \%)$, gemuk 2 responden (1,5\%), sangat gemuk 2 responden (1,5\%) (Yulni, 2013).

Maka Peneliti berasumsi bahwa letak wilayah antara Pesisir dan Pegunungan dari sumber pendapatan dari wilayah masing-masing tidak mempengaruhi kejadin obesisitas angka kejadian obesitas di wilayah pesisir masih banyak yang mengalami gemuk, dan beresiko menjadi obesitas di masa yang akan datang.

Dari status gizi yang didapatkan dari wilayah Pegunungan dari anak remaja awal sangat kurus di temukan 1 responden (05\%), sangat kurus 7 responden $(3,3 \%)$, Gizi normal 164 responden $(78,1 \%)$, gemuk 21 responden $(10,0 \%)$, dan anak yang remaja awal yang di temukan berstatus gizi obesitas yaitu 17 responden $(8,1 \%)$. Daerah perbukitan dominan akan sayur-mayur, dan hasil perkebunan. Namun masih banyak anak remja awal yang mengemsumsi berbagai jenis makanan yang siap saji.

Penelitian ini sejalan dengan penelitian yang dilakukan sebelumnya oleh Mahdia, Hamam Hadi dan Susetyowati. Dengan Judul Paparan Iklan Junk Food dan Pola Konsumsi Junk Food Sebagai Faktor Risiko Terjadinya Obesitas Pada Anak Sekolah Dasar Kota dan Desa di Daerah Istimewa Yogyakarta Selain itu, berdasarkan asupan zat gizi yang berasal dari junk food, diketahui bahwa asupan energi, lemak jenuh, dan natrium memiliki hubungan yang signifikan dengan kejadian obesitas $(\mathrm{p}<0,05)$. Anak SD dengan asupan energi junk food yang tinggi ( $\geq 762$ $\mathrm{kkal} / \mathrm{hari}$ ) memiliki risiko 1,58 kali menjadi obesitas, asupan lemak jenuh junk food yang tinggi $(\geq 12,6 \mathrm{~g} / \mathrm{hari})$ memiliki risiko 1,74 kali menjadi obesitas, dan asupan natrium junk food yang tinggi ( $\geq 1072 \mathrm{mg} /$ hari) memiliki risiko $1,83 \mathrm{kali}$ menjadi obesitas. Sebaliknya, variabel frekuensi konsumsi junk food perbulan dan asupan sukrosa junk food ternyata tidak memiliki hubungan dengan kejadian obesitas ( $>>0,05)$. (Nurwati, Hadi, \& Julia, 2013).

Teori ini sejalan dengan penelitian yang di kemukakan oleh Mahdia, Hamam Hadi dan Susetyowati, bahwa Pemilihan jenis dan jumlah makanan, serta berpengaruh terhadap gaya hidup keluarga yang juga akan berdampak pada anak, pendapatan yang tinggi tidak selalu menjamin beragam dan bermutunya bahan pangan yang dikonsumsi tetapi dapat juga mengarah pada pemilihan bahan makanan yang lebih praktis, enak, siap santap, dan lebih banyak mengandung lemak, minyak, dan bahan lainnya yang dapat menyebabkan obesitas (Octari, Liputo, \& Edison, 2014). 
Peneliti berasumsi bahwa ditemukan jumlah responden yang gemuk (overweight) dengan jumlah 44 responden lebih banyak dibandingkan obesitas dengan jumlah 27 responden, hal ini disebabkan karena rata-rata responden yang mengalami gemuk dan obesitas sering mengomsumsi makanan ringan seperti, gerupuk, sosis, dan makanan yang berminyak seperti gorengan, nugget, telatela, ataupun makanan siap saji seperti nasi kuning, nasi santan, dan bakso dan akan memicu berbagai macam penyakit seperti hipertensi, osteoporosis di masa yang akan datang.

Berdasarkan Tabel 3 Dari hasil penelitian status gizi anak remaja awal umur 11 tahun jenis kelamin laki-laki tidak ditemukan status gizi diwilayah Pesisir sedangkan diwilayah Pegunungan di temukan anak yang berstatus gizi gemuk 1 responden dan gemuk 1 responden. Berdasarkan umur 12 tahun di temukan status gizi anak remaja awal jenis kelamin laki-laki di wilayah Pesisir tidak di temukan sangat kurus sedangkan di wilayah Pegunungan di temukan 1 responden yang berstatus gizi sagat kurus, diwilayah Pesisir yang berstatus kurus di temukan 1 responden di wilayah Pegunungan tidak di temukan responden, diwilayah Pesisir yang berstatus gizi normal di temukan 2 responden sedangkan diwilayah Pegunungan tidak di temukan responden, status gizi gemuk di wilayah Pesisir tidak ditemukan responden sedangkan di wilayah Pegunungan di temukan anak remaja awal yang berstatus gizi gemuk 1 responden, di wilayah Pesisir anak yang berstatus gizi obesitas di temukan 2 responden sedangkan diwilayah Pegunungan di temukan 2 responden dari hasil pembahasan berdasarkan umur dan wilayah wilayah pesisir dengan keterbatasan sumber daya alam mempengeruhi status gizi anak.

Berdasarkan umur 13 tahun anak laki-laki berstatus gizi sangat kurus diwilayah Pesisir di temukan 1 responden sedangkan diwilayah Pegunungan tidak ditemukan responden, anak remaja awal yang berstatus gizi kurus diwilayah Pesisir ditemukan 2 responden sedangkan diwilayah Pegunungan 4 responden, anak yang berstatus gizi normal diwilayah Pesisir di temukan 47 responden sedangkan diwilayah Pegunungan ditemukan 48 responden, status gizi gemuk anak remaja awal diwilayah Pesisir 2 responden sedangkan diwilayah Pegunungan 3 responden, status gizi obesitas anak remaja awal diwilayah Pesisir 1 responden sedangkan diwilayah Pegunungan 5 responden dari hasil pembahasan umur 15 tahun anak remaja awal obesitas diwilayah pegunungan lebih 
tinggi dibandingkan diwilayah pesisir ini pengaruhi oleh berbagai faktor misalnya makanan dan kurangnya aktifitas fisik.

Berdasarkan umur 14 tahun anak laki-laki yang berstatus gizi sangat kurus di wilayah Pesisir tidak di temukan responden begitupun diwilayah Pegunungan, yang berstatus kurus di wilayah Pesisir di temukan 4 responden sedangkan diwilayah Pegunungan di temukan 1 responden, anak yang berstatus gizi normal diwilayah Pesisir di temukan 20 responden sedangkan diwilayah Pegunungan 24 responden, anak yang berstatus gizi gemuk di temukan di wilayah Pesisir 3 responden sedangkan diwilayah Pegunungan tidak di temukan responden, anak yang berstatus gizi obesitas di wilayah Pesisir di temukan 1 responden sedangkan diwilayah Pegunungan tidak ditemukan responden.

Berdasarkan umur 15 tahun status gizi anak laki-laki sangat kurus diwilayah Pesisir tidak ditemukan responden begitupun di wilayah Pegunungan, anak remaja awal yang berstatus gizi kurus di wilayah Pesisir tidak di temukan responden sedangkan diwilayah Pegunungan di temukan 1 responden. Berdasarkan umur 16 tahun status gizi sangat kurus diwilayah Pesisir sangat kurus dan status gizi normal di temukan masing-masing 1 responden sedangkan diwilayah Pegunungan tidak ditemukan responden. dari pembahasan diatas berdasasarkan umur anak remaja awal laki-laki yang mengalami status gizi kurus berada pada umur 14 tahun begitupun dengan status gizi gemuk terjadi pada umur 14 tahun sedangkan status gizi obesitas lebih sering terjadi pada umur 12 tahun pada anak remaja awal laki-laki.

Dari hasil penelitian status gizi anak remaja awal umur 11 tahun jenis kelamin Perempuan diwilayah Pesisir tidak di temukan status gizi sedangkan diwilayah Pegunungan di temukan anak berstatus gizi gemuk 1 responden.

Berdasarkan umur 12 tahun anak remaja awal perempuan di temukan status gizi normal 1 responden diwilayah Pesisir begitupun di wilayah pegunungan 1 responden, anak remaja awal yang berstatus gizi gemuk diwilayah Pesisir di temukan 10 responden sedangkan diwilayah Pegunungan 6 responden in menunjukkan bahwa anak yang mengalami status gizi gemuk di antara dua wilayah, wilayah Pesisir lebih tinggi angka kejadian status gizi gemuk di bandingkan di Pegunungan, anak yang berstatus gizi obesitas diwilayah Pesisir ditemukan 2 responden sedangkan diwilayah Pegunungan 5 responden hal ini berbanding terbalik dengan status gizi gemuk dan status gizi obesitas di anatara dua wialayah tersebut di mana status gizi 
gemuk lebih tinggi diwilayah Pegunungan di bandikan diwilayah Pesisir.

Berdasarkan umur 13 tahun di temukan anak jenis kelamin perempuan status gizi status gizi sangat kurus ditemukan diwilayah Pesisir 1 responden sedangkan diwilayah Pegunungan tidak ditemukan responden, status gizi kurus anak remaja awal diwilayah Pesisir di temukan 7 responden sedangkan diwilayah Pegunungan di temukan 1 responden, status gizi normal diwilayah Pesisir ditemukan 63 responden sedangkan di wilayah Pegunungan 61 responden, anak yang berstatus gizi gemuk diwilayah Pesisir di temukan 3 responden sedangkan diwilayah Pegunungan 9 responden, anak yang berstatus gizi obesitas ditemukan diwilayah Pesisir 2 responden sedangkan diwilayah Pegunungan 3 responden, pada umur 13 tahun angka kejadian status gizi kurus diwilayah pesisir lebih tinggi di bandikan dipegunungna berbanding terbalik dengan diwilayah pegungan dengan status gizi gemuk, angka kejadian gemuk diwilayah lebih tinggi dibandingkan dengan pesisir

Berdasarkan umur 14 tahun diwilayah Pesisir ditemukan anak jenis kelamin perempuan yang berstatus kurus 1 responden sedangkan di wilayah Pegunungan tidak ditemukan anak yang berstatus gizi kurus, status gizi anak normal diwilayah pesisir di temukan 31 responden sedangkan diwilayah Pegunungan 21 responden, anak remaja awal yang berstatus gizi gemuk dan obesitas diwilayah Pesisir masing 2 responden sedangkan diwilayah Pengunungan tidak di temukan anak yang berstatus gemuk dan obesitas.

Berdasarkan umur 15 tahun anak remaja awal yang berstatus gizi sangat kurus diwilayah Pesisir dan Pegunungan tidak ditemukan responden, status gizi kurus diwilayah Pesisir ditemukan 2 responden sedangkan diwilayah Pegunungan tidak ditemukan responden, anak yang berstatus normal diwilayah Pesisir 4 responden begitupun diwilayah Pegunungan 4 responden, anak yang berstatus gizi gemuk diwilayah Pesisir 3 responden dan anak remaja awal yang obesitas tidak ada responden sedangkan diwilayah Pegunungan tidak di temukan status gizi gemuk maupun obesitas.

Berdasarkan umur 16 tahun status gizi anak remaja awal jenis kelamin perempuan diwilayah Pesisir ditemukan status gizi normal 3 sedangkan diwilayah Pegunungan tidak ditemukan responden. dari hasil pembahasan anak remaja awal perempuan diwilayah Pesisir dan Pegunungan menunjukkan bahwa nilai tertinggi yaitu normal di umur 13 tahun 161 responden kemudian status gizi normal 
tertinggi diwilayah pesisir yaitu 63 responden pada umur 13 tahun.

Penelitian ini di dukun dengan teori supariasa bahwa status gizi merupakan keadaan kesehatan tubuh seseorang atau sekelompok orang yang diakibatkan oleh komsumsi, penyerapan (absorption) dan penggunaan (utilization) zat gizi makanan (Supariasa, Bakri, \& Fajar, 2014). begitupun dengan teori yang di kemukakan oleh Maharibe bahwa gizi normal adalah susunan makanan mengandung zat-zat gizi dalam jenis dan jumlah yang sesuai dengan kebutuhan tubuh, dengan memerhatikan prinsip keanekaragaman atau variasi makanan, aktivitas fisik, kebersihan, dan berat badan (BB) ideal, respon terhadap pengetahuan dan sikap terhadap gizi seimbang yang meliputi mengomsumsi makanan seimbang dan berperilaku hidup sehat ( Maharibe, Kawengian, \& Bolang, 2013).Penelitian ini sejalan dengan penelitian dari Cholida Auliya yang berjudul Profil Status Gizi Balita Ditinjau Dari Topografi Wilayah Tempat Tinggal (Studi Di Wilayah Pantai Dan Wilayah Punggung Bukit Kabupaten Jepara Dari hasil penelitian menunjukkan bahwa letak topografi tempat tinggal tidak memberikan perbedaan pada status gizi balita. Hal ini dibuktikan dalam analisis bivariat memperoleh nilai $\mathrm{p}=0,59>0,05$. Berdasarkan hasil analisis tersebut diketahui bahwa sebanyak $66,7 \% \quad$ (20 Balita) yang bertempat tinggal di wilayah pesisir berstatus gizi baik dan diwilayah punggung bukit sebesar 83,3\% (25 Balita. (Auliya \& Budiono, 2015).

Maka Peneliti berasumsi bahwa angka kejadian overwegiht dan obesitas lebih dominan terjadi pada jenis kelamin perempuan di bandingkan laki-laki di karenakan anak laki-laki lebih sering bermain dan lebih banyak aktivitas fisik seperti bermain bola, berlari dan melompat. yang dapat membakar lemak dalam tubuh sedangkan perepuan dengan melihat aktivitasnya anak perempuan lebih cendrung berada dalam rumah ini menunjukkan bahwa anak perempuan lebih kurang aktivitas yang di lakukan di bandingkan anak remaja awal laki-laki.

\section{KESIMPULAN DAN SARAN}

Dari hasil penelitian yang di lakukan maka dapat di simpulkan Status gizi anak remaja awal di SMPN 14 dan 10 Bulukumba di wilayah pegunungan memiliki status gizi obesitas dan status gizi anak remaja awal di SMPN 32 Bulukumba diwilyah pesisir memiliki Status gizi Gemuk. Agar penelitian ini dapat memberikan informasi mengenai Status Gizi anak remaja diwilayah Pegunungan dan Pesisir di Kabupaten Bulukumba, penelitian ini dapat menjadi informasi yang berguna untuk semua pihak tertentu. peran guru di sekolah sangat 
dibutuhkan guna memberikan pendidikan masalah gizi yang baik. dari pihak tenaga kesehatan perlu melakukan sosialisasi mengenai asupan gizi yang di butuhkan oleh anak remaja awal upaya untuk meningkatkan dan mempertahankan status gizi normal Agar penelitian ini dapat menjadi bahan referensi untuk penelitian selanjutnya.

\section{DAFTAR PUSTAKA}

Almaster, S. (2009). Prinsip Dasar I LMU

GIZI. Jakarta: Gramedia Pustaka Utama,

Auliya, C., \& Budiono, o W. (2015). Frofil Status Gizi Ditinjau dari Tofo Grafi Wilayah Tempat Tinggal (Studi Wilayah Pantai Dan Pegunungan Bukit Kabupaten Jepara). Unnes Journal of Public Health.

Budiyati, Wanda, D., \& Hartoyo, M. (2013). Hubungan Indeks Massa Tubuh Ayah Dan Ibu Dengan Kejadian Obesitas Pada Anak Usia Sekolah Di SD Islam Al-Azhar 14 Kota Semarang. Prosiding Seminar Nasional

Damopolii, W., Mayulu, N., \& Masi, G. (2013). Hubungn Komsumsi Fastfood Dengan Kejadian Obesitas Pada Anak SD Di Kota Manado. Ejournal keperawatan

Danari, A. L., Mayulu, N., \& Bala, F. O. (2013). Hubungan Aktifitas Fisik Dengan Kejadian Obesitas Pada Anak SD Kota Manado Ejournal Keperawatan

Dharma, K. K. (2012). Metodologi Penelitian Keperawatan. DKI Jakarta: Trans Info Media

Dinas Kesehatan Kab/Kota Se Sul-Sel. (2015). Profil Kesehtan Prov. Sulawesi Selatan
Dinkes Kota Bulukumba. (2016). Profil kesehatan Kab/kota Bulukumba prov- sulaweisi selatan

Erika, K. A., \& Nurachmah, E. (2014). Pengaruh Pendekatan Child Healthcare Model dan Transtheoretical Model terhadap Asupan Makan Anak Overweight dan Obesitas. Jurnal Kesehatan Masyarakat Nasional.

Faridah, D., \& Indriani. (2017). Faktor Yang Berhubungan Dengan Overweight Dan Obesitas Pada Anak Usia Prasekolah Di TK "Aisyah Bustanul Athful Kota Yogyakarta

K.M., \& Fitriani, D. Y. (2014). Faktor Resiko Kejadian Overweight Pada Anak Stunting Usia Sekolah Dasar Di semaran Timur Journal of Nutrition College, 3

Kemenkes. (2010). Jakarta:Propil Kesehatan Indonesia. Kementrian Kesehatan Republik Indonesia

Kemenkes. (2011). Kementrian Kesehatan, Jakarta:Propil Kesehatan Indonesia,

Kementrian Kesehatan Republik Indonesia.

Kussoy, K., Fatimawali, \& Kepel, B. (2013). Prevalensi Obesitas Pada Remaja Di Kabupaten Minahasa. Jurnal e-Biomedik.

Maharibe, C.C., Kawengian, S. E., \& Bolang, A.S. (2013). Hubungan Pengetahuan Gizi Seimbang Dengan Pratik Gizi Seimbang Fakultas Kedokteran Universitas Samratulangit. Bio Medik.

Nurwati, E., Hadi, H., \& Julia, M. (2013). Paparan Iklan Junk Food Dan Pola Konsumsi Junk Food Sebagai Jouernal Gizi Dan Dieteik Indonesia.

Octari, C., Liputo, N. I, \& Edison. (2014). Hubungan Status Sosial Ekonomi dan Gaya Hidup dengan Kejadian Obesitas pada Siswa SD Negeri 08 Alang Lawas Padang. Jurnal Kesehatan Andalas 
Prasetyorini, H. T., \& Febrijanto, y. (2010). Studi Tinkat Pengetahuan Tentang Metode Penurunan Berat Badan Pada Mahasiswa Overweight. Jurnal STIKES RS. Baptis Kediri.

Putri, N. R., Wibawa, A., Sugiritama, I. W., \& Muliarta, I M. (2016). Wanita Overweight Dan Obesitas Memiliki Sudut Eversi Calcaneus Lebih Besar Dan Ekstensibilitas Gastrocnemius Lebih Kecil Dari Pada Wanita Normal Majalah Ilmiah Fisioterapi Indonesia (MIFI).

Riskesdas. (2010). badan penelitian dan pengembangan kesehatan, depertemen kesehatan, republik indonesia.

Riskesdas. (2013). Riset Keshatan Dasar, badan penelitian dan pengembangan kesehatan, depertemen kesehatan, republik indonesia.

Riskesdas Provinsi Sul-Sel. (2007-2013). Kementrian Kesehatan RI Badan Penelitian dan Pengebangan Kesehatan

Sari, V. P. (2012). Perbedaan Prestasi Belajar Antara Anak Sekolah Dasar Penderita Obesitas Dan Status Gizi Normal. Jurnal Kesehatan Masyarakat.

Setiadi. (2013). Konsep Dan Pratik Penulisan Riset Keperawatan. Yogyakarta: Graha Ilmu

Soetjiningsih. (2010). Tumbuh Kembang Remaja Dan Permasalahanya. Jakarta Sagung Seto

Soslia, A., Ganiajri, F., Lestari, P. P., \& Sari, R. W. (2014). Keperawatan Medikal Bedah (Vol. 8). (J. Mulyanto, Yudhistira, \& A. P. Tunggono, Penerj.)Singapore: Salemba Medika.

Supariasa, I N., Bakri, B., \& Fajar, I. (2014). Penelitian Status Gizi. Jakarta: Buku Kedokteran EGC
Suryani, D., Sabrina, Y., Cholidah, R, Ekawanti, A., \& Andari, M Y. (2017). Studi Status Gizi, Pola Makan Serta Aktivitas Pada Anak Sekolah Di Kota Mataram. Jurnal Kedokteran Unram.

Suryaputra, K. \& Nadhiroh, S. R. (2012). Perbedaan Pola Makan Dan Aktivitas fisik Antara Remaja Obesitas Dan Non Obesitas. Makara Kesehatan

Tanto, C., Liwang, F., Hanifati, S., \& Pradipta, E A. (2014). Kapita Selekta Kedokteran, Jakarta: Media Eesculapius,

Townsend, C. M. Beauchamp, R. D., Evers, B. M., \& Mattox, K. L. (2010). Buku Saku Ilmu Bedah Sabiston. Jakarta Buku Kedokteran EGC

Watulingas, I., K ulingas, I., Rampengan, J. J., \& Polii, H. (2013). Pengaruh Latihan Fisik Aerobik Terhadap VO2 Max Pada Mahasiswa Pria Dengan Berat Badan Lebih (Overweight), Jurnal e-Biomedik.

Yulni. (2013). Hubungan Asupan Zat Gizi Makro Dengan Status Gizi Pada Anak Sekolah Dasar Di Wilayah Pesisir Kota Makassar. Jurnal MKMI. 
Tabel 1 Distribusi frekuensi berdarkan karateristik responden

\begin{tabular}{ccccccc}
\hline \multirow{2}{*}{ Jenis Kelamin } & \multicolumn{2}{c}{ Pesisir } & \multicolumn{2}{c}{ Pegunungan } & \multicolumn{2}{c}{ Total } \\
\cline { 2 - 7 } & $\mathbf{F}$ & $\mathbf{\%}$ & $\mathbf{F}$ & $\mathbf{\%}$ & $\mathbf{F}$ & $\mathbf{\%}$ \\
\hline Laki-Laki & 93 & 40,3 & 98 & 46,3 & 191 & 43.3 \\
Perempuan & 138 & 59,7 & 112 & 53,3 & 250 & 56,7 \\
\hline \multirow{2}{*}{ Umur } & \multicolumn{2}{c}{ Pesisir } & \multicolumn{2}{c}{ Pegunungan } & \multicolumn{2}{c}{ Total } \\
\cline { 2 - 7 } & $\mathrm{F}$ & $\%$ & $\mathrm{~F}$ & $\%$ & $\mathrm{~F}$ & $\%$ \\
\hline 11 Tahun & 0 & 0 & 3 & 1,4 & 3 & 0,7 \\
12 tahun & 18 & 7,8 & 16 & 7,6 & 34 & 7,7 \\
13 tahun & 129 & 55,8 & 134 & 63,8 & 263 & 59,6 \\
14 tahun & 64 & 27,7 & 46 & 21,9 & 110 & 24,9 \\
15 tahun & 15 & 6,5 & 11 & 5,2 & 26 & 5,9 \\
16 tahun & 5 & 2,2 & 0 & 0 & 5 & 1,1 \\
\hline Total & $\mathbf{2 3 1}$ & $\mathbf{1 0 0}$ & $\mathbf{2 1 0}$ & $\mathbf{1 0 0}$ & $\mathbf{4 4 1}$ & $\mathbf{1 0 0}$ \\
\hline
\end{tabular}

Tabel 2 Distribusi Jumlah Responden Berdasarkan Status Gizi

\begin{tabular}{ccccccc}
\hline Status & \multicolumn{2}{c}{ Pesisir } & \multicolumn{2}{c}{ Pegunungan } & \multicolumn{2}{c}{ Total } \\
\cline { 2 - 7 } Gizi & F & \% & F & \% & F & \% \\
Sangat Kurus & 3 & 1,3 & 1 & 0,5 & 4 & 0,9 \\
Kurus & 18 & 7,8 & 7 & 3,3 & 25 & 5,7 \\
Normal & 177 & 76,6 & 164 & 78,1 & 341 & 77,3 \\
Gemuk & 23 & 10,0 & 21 & 10,0 & 44 & 10,0 \\
Obesitas & 10 & 4,3 & 17 & 8,1 & 27 & 6,1 \\
\hline Total & $\mathbf{2 3 1}$ & $\mathbf{1 0 0}$ & $\mathbf{2 1 0}$ & $\mathbf{1 0 0}$ & $\mathbf{4 4 1}$ & $\mathbf{1 0 0}$ \\
\hline
\end{tabular}

Tabel 3

Distribusi jumlah responden menurut jenis kelamin, umur dan status gizi di SMPN 32 Bulukumba wilayah Pesisir Kabupaten Bulukumba

\begin{tabular}{|c|c|c|c|c|c|c|c|}
\hline \multirow[b]{2}{*}{$\begin{array}{c}\text { Jenis } \\
\text { Kelamin }\end{array}$} & \multirow[b]{2}{*}{ Umur } & \multicolumn{5}{|c|}{ Status Gizi Pesisir } & \multirow[b]{2}{*}{ Total } \\
\hline & & $\begin{array}{l}\text { Sangat } \\
\text { Kurus }\end{array}$ & Kurus & Normal & Gemuk & Obesitas & \\
\hline \multirow{7}{*}{ Laki-Laki } & 11 Tahun & 0 & 0 & 0 & 0 & 0 & 0 \\
\hline & 12 tahun & 0 & 1 & 2 & 0 & 2 & 5 \\
\hline & 13 tahun & 1 & 2 & 47 & 2 & 1 & 53 \\
\hline & 14 tahun & 0 & 4 & 20 & 3 & 0 & 27 \\
\hline & 15 tahun & 0 & 0 & 5 & 0 & 1 & 6 \\
\hline & 16 tahun & 1 & 0 & 1 & 0 & 0 & 2 \\
\hline & Total & 2 & 7 & 75 & 5 & 4 & 93 \\
\hline \multirow{8}{*}{ Perempuan } & 11 Tahun & 0 & 0 & 0 & 0 & 0 & 0 \\
\hline & 12 tahun & 0 & 0 & 1 & 10 & 2 & 13 \\
\hline & 13 tahun & 1 & 7 & 63 & 3 & 2 & 76 \\
\hline & 14 tahun & 0 & 2 & 31 & 2 & 2 & 37 \\
\hline & 15 tahun & 0 & 2 & 4 & 3 & 0 & 9 \\
\hline & 16 tahun & 0 & 0 & 3 & 0 & 0 & 3 \\
\hline & Total & 1 & 11 & 102 & 18 & 6 & 138 \\
\hline & 11 Tahun & 0 & 0 & 0 & 0 & 0 & 0 \\
\hline https://doi. & & & & $\begin{array}{r}\text { Keseh } \\
\text { Vc }\end{array}$ & Panrita & $\begin{array}{l}\text { Isada | } \\
t 2020\end{array}$ & 30 \\
\hline
\end{tabular}




\begin{tabular}{cccccccc}
\hline \multirow{5}{*}{ Total } & 12 tahun & 0 & 1 & 3 & 10 & 4 & 18 \\
& 13 tahun & 2 & 9 & 110 & 5 & 3 & 129 \\
& 14 tahun & 0 & 6 & 51 & 5 & 2 & 64 \\
& 15 tahun & 0 & 2 & 9 & 3 & 1 & 15 \\
& 16 tahun & 1 & 0 & 4 & 0 & 0 & 5 \\
\hline
\end{tabular}

Tabel 4

Distribusi Jumlah Responden Menurut Jenis Kelamin, Umur dan Status Gizi di SMPN 14 Bulukumba SMPN 18 Bulukumba wilayah Pegunungan Kabupaten Bulukumba

Jenis

Kelamin
Umur

Laki Laki 11 Tahun

\begin{tabular}{ccc} 
& & Kurus \\
\hline Laki Laki & 11 Tahun & 0 \\
& 12 tahun & 1 \\
& 13 tahun & 0 \\
& 14 tahun & 0 \\
& 15 tahun & 0 \\
& 16 tahun & 0 \\
\hline \multirow{3}{*}{ Perempuan } & Total & 1 \\
& 11 Tahun & 0 \\
& 12 tahun & 0 \\
& 13 tahun & 0 \\
& 14 tahun & 0 \\
& 15 tahun & 0 \\
& 16 tahun & 0 \\
\hline Total & Total & 0 \\
& 11 Tahun & 0 \\
& 12 tahun & 1 \\
& 13 tahun & 0 \\
& 14 tahun & 0 \\
& 15 tahun & 0 \\
16 tahun & 0 \\
\hline & Total & 1
\end{tabular}

Status Gizi Pegunungan

Total

\begin{tabular}{llll}
\hline $\begin{array}{c}\text { Sangat } \\
\text { Kurus }\end{array}$ & Kurus Normal Gemuk Obesitas
\end{tabular}

$\begin{array}{ccccc}0 & 0 & 1 & 1 & 2 \\ 0 & 0 & 1 & 2 & 4 \\ 4 & 48 & 3 & 5 & 60\end{array}$

$\begin{array}{lllll}1 & 24 & 0 & 0 & 25\end{array}$

$\begin{array}{lllll}1 & 5 & 0 & 1 & 7\end{array}$

$\begin{array}{ccccc}0 & 0 & 0 & 0 & 0 \\ 6 & 77 & 5 & 9 & 98 \\ 0 & 0 & 1 & 0 & 1\end{array}$

$\begin{array}{ccccc}0 & 1 & 6 & 5 & 12 \\ 1 & 61 & 9 & 3 & 74 \\ 0 & 21 & 0 & 0 & 21 \\ 0 & 4 & 0 & 0 & 4 \\ 0 & 0 & 0 & 0 & 0 \\ 1 & 87 & 16 & 8 & 112 \\ 0 & 0 & 2 & 1 & 3 \\ 0 & 1 & 7 & 7 & 16 \\ 5 & 109 & 12 & 8 & 134 \\ 1 & 45 & 0 & 0 & 46 \\ 1 & 9 & 0 & 1 & 11 \\ 0 & 0 & 0 & 0 & 0 \\ 7 & 164 & 21 & 17 & 210\end{array}$

